\title{
EFFECT OF RECOMBINANT BOVINE SOMATOTROPIN TREATMENT ON MILK PRODUCTION AND REPRODUCTIVE PERFORMANCE OF EWES AND GROWTH PERFORMANCE OF THEIR OFFSPRINGS. \\ Abdel-Khalek, A.E.*; T.A.M. Ashmawy**; E.S.H. El-Gohary**; A.A. Sallam ${ }^{\star *}$ and Doaa F. Teleb ** \\ * Animal Production Department, Faculty of Agric., Mansoura Univ. \\ ** Animal Production Research Institute, Agricultural Research Center.
}

\begin{abstract}
This study was carried out to investigate the effect of administration of bovine somatotropin on milk yield, milk composition, reproductive performance of Rahmani crossbreed ewes, as well as, offspring growth. A total number of 40 mature healthy Rahmani crossbred ewes (1/2 Finnish Landrace x 1/2 Rahmani) aged from 3 to 4 years were divided into two similar groups (control and treatment). Ewes in the first group were injected with saline solution and served as a control, while those in the second group were s.c. injected with $160 \mathrm{mg}$ recombinant bST at 14-day interval from one-month pre-partum until 3 months post-partum. Ewes were monitored for sign of oestrus and those observed in heat were mated using a fertile ram (breeding season from April to June). Milk yield and composition were determined throughout 8 lactation weeks. Results show that LBW of ewes at pre-partum and during the suckling period was not affected by rbST treatment, however, treated ewes were heavier $(\mathrm{P}<0.05)$ by about $5 \%$ than the control ones only during late post-partum. Administration of rbST increased $(\mathrm{P}<0.05)$ average daily milk yield of ewes during the $1^{\text {st }}$ eight weeks of lactation, and the magnitude of the increase during the eight lactation weeks ranged between 16 to $33 \%$. Milk fat, protein and total solids percentages were significantly lower $(\mathrm{P}<0.05)$ in treated than in control ewes. Meanwhile, lactose and ash contents did not differ significantly between the two groups. Male and female lambs of treated ewes were heavier $(\mathrm{P}<0.05)$ during the suckling period compared with those of the control group. Lambs of treated ewes reached the weaning weight (12 $\mathrm{kg}$ ) earlier (at 6 and 7 weeks for male and female, respectively) than those of the control ewes (8 weeks). Average daily gain of male and female lambs of treated ewes was higher (221 and $182 \mathrm{~g} /$ day, respectively) than that of the control (163 and $170 \mathrm{~g} /$ day, respectively). Treatment with rbST increased $(\mathrm{P}<0.05)$ oestrus/mating rate $(40 \mathrm{vs} .70 \%)$ and reduced post-partum period of lambing ewes by about one month as compared to untreated ewes. Moreover, ewes treated with rbST showed greater $(\mathrm{P}<0.05)$ number of ovarian follicles and corpus lutea (18 and 21) than that of the control ones (5 and 10), respectively. Lambing rate was lower $(\mathrm{P}<0.05)$ in control than in treated ewes $(30$ and 75 vs. 60 and $85.7 \%$ ), respectively.

In conclusion, s.c. injection of $160 \mathrm{mg}$ rbST at 14-day interval during one-month pre-partum and 3 months post-partum improved productive (milk yield) and reproductive (lambing rate) performance of ewes and their offspring growth.
\end{abstract}

Keywords: Ewes, somatotropin, milk yield, milk composition, lambs performance, reproductive performance.

\section{INTRODUCTION}

Great attention was focused on recombinant bovine somatotropin because of the increase of up to $40 \%$ in milk yield achieved with rbST in already high yielding cows. Subsequent lactation studies substantiated the positive response of milk yield to administration (Putuam et al., 1999). Generally, administration of rbST to lactating dairy cows increased the yield of milk production. The 
magnitude of response to particular rbST depends on biological variation, stage of lactation, and management parameters (Akers, 2002).

For lactating ewes, a few experiments have been carried out with bST, but none has used a sustained-release formulation. For example, Westbrook et al. (1993) utilized the immunization against somatotropin release-inhibiting factor; Sandles et al. (1988)) used daily rbST injections; and McDowell et al. (1987) used intra-arterial infusions of growth hormone. In lactating dairy ewes, Fernandez et al. (1995) showed that rbST treatment increased milk yield $(P<0.01)$ over the control during different lactation weeks. The largest increase in milk yield was at $160 \mathrm{vs} .80$ or $240 \mathrm{mg}$ of rbST by which milk yields increased by 34.1 and $53.2 \%$ and $6 \%$ fat corrected milk by 36.9 and $51.8 \%$ during $3-8$ and $11-23$ weeks lactation, respectively. Neither mastitis nor milk somatic cell count (SCC) were affected by rbST treatment. Milk composition is not changed by rbST administration (Downer et al., 1993), but milk fat content can be increased at the beginning of lactation (Bitman et al., 1984), and milk protein can be reduced at higher rbST doses (Eppard et al., 1985).

Many studies have been evaluated the effects of rbST on dairy cow reproduction. These effects of rbST on reproduction were related to rbST dosetime of initiation of treatment, time of initiation of breeding and control of other factors such as nutritional status and milk production of cows (Esteban et al., 1994). In this respect, rbST treatment increased fertility without indication of increases in pregnancy failure (Chalupa et al., 1996) and ovulation rate of heifers (Gong et al., 1993b).

The galactopoletic effects of rbST are well established in sheep (Stelwagen et al., 1993) and dairy goats (Knight, 1992). However, a few studies have been investigated the effect of rbST on milk production in lactating dairy ewes and goats. The milk yield responses to rbST treatment in goats and sheep are more variable than that in cows (Davis et al., 1999).

Therefore, the current work aimed to study the effect of rbST treatment (160 $\mathrm{mg} / \mathrm{ewe}$ at 14-day interval) during pre- and post-partum period on productive (LBW and milk production); reproductive performance (oestrous and ovarian activities and fertility) of $1 / 2$ Finnish Landrace $\times 1 / 2$ Rahmani ewes and their offspring growth.

\section{MATERIALS AND METHODS}

This study was carried out at Sakha Experimental Station- Animal Production Research Institute- Agricultural Research Center- Ministry of Agriculture.

At the beginning of the experiment ( January), Forty mature healthy Rahmani crossbred ewes (1/2 Finnish Landrace x 1/2 Rahmani) at late pregnancy, aged 3 to 4 years with average body weight $53.3 \mathrm{~kg}$ were divided into two equal groups (control and treatment), according to their live body weight (LBW) and age. First group were served as a control and injected with saline solution, while those in the second group were treated with a subcutaneous injection of $160 \mathrm{mg}$ recombinant bovine somatotropin (Sometribove; Monsanto Europe, Brussels, Belgium) at 14-day intervals for an experimental period of 120 days according to Fernandez et al. (1995). 
Animals were fed according to NRC (1985) allowances. All animals were fed daily with concentrate feed mixture (CFM) at 9 a.m. and 4 p.m. The amounts of CFM were adjusted according to the physiological and productive stage. Fresh water was available all times. All animals were kept in a semi-open shaded yard during the experimental period. Ewes live body weights were recorded biweekly. The experimental period were consisted of 3 intervals, late pregnancy (30 day pre-partum), suckling (60 day post-partum) and breeding season (45 days).

Milk yield was recorded weekly throughout 8 lactation weeks using milk suckling technique. Lambs were isolated from their mothers during previous night and body weight was recorded (to the nearest $10 \mathrm{gm}$ ) at the morning (7.0 a.m.). Lambs were left to suckle their dams for 30 minutes, and then body weight was recorded again. The residual milk was hand milked and recorded. Similar procedure was repeating at the evening suckling at 5.30 p.m. The differences in lamb weight before and after suckling (the two suckling) were added to calculate the daily intake of suckling lambs. Milk intake plus milk removed by hand milking represented daily milk yield. All lambs were weaned irrespective of weight around $12 \mathrm{~kg}$ LBW.

Milk samples from morning and evening milking were collected during the suckling period (8 weeks) from five ewes randomly selected from each group. Milk fat content was determined using the Gerber's method (B.S.I., 1952). Protein content was determined by means of micro-Kjeldahl procedure according to Ling (1963). Total solids, lactose and ash in milk samples were also determined according to B.S.I. (1952), Barnett and Abdel-Tawab (1957) and A.O.A.C. (1984), respectively.

During the post-partum period ewes were monitored for sign of oestrus by introducing well trained ram to ewes two times daily (at 8.0 a.m. and 4.0 p.m.) for 35 days. Ewes exhibited estrus was mated using fertile ram.

Blood samples were collected weekly from the jugular vein of three ewes that were randomly selected from each group during post-partum period [ $1=$ last week in January (Jan.), 2- 5= weeks in February (Feb), 6- 7 weeks in March (Mar.)]. Samples were left to clot at room temperature for at least $4 \mathrm{~h}$. Sera were separated by centrifugation of the blood at $1500 \times \mathrm{g}$ for $20 \mathrm{~min}$ and stored at -20 C until assayed.

Quantitative determination of serum progesterone was carried out using radioimmunoassay kits (catalog No. 1188 manufactured by Immunotech, France). The assay is based on competition reaction with sensitivity $0.03 \mathrm{ng} / \mathrm{ml}$ (Bojanic et al., 1991). The coefficient of variation for the intra- and inter- assay were 5.4 and $9.1 \%$, respectively. Progesterone concentrations were detected using automatic Mini-Gama counter (LKB 1275, USA).

Laparoscopy technique was employed to visualize and examine the changes in ovarian structures using walf/8933/7mm Laparoscopy (USA, German lens system). Laparoscopy was performed once during the period from day 5 to day 12 after mating .The ovaries were examined for presence of either corpora lutea (CL), large follicles (LF) which more than $2 \mathrm{~mm}$, and small follicles (SF) which less than $2 \mathrm{~mm}$ according to Deghedy (2006). Ewes were deprived from feeds and water for $24 \mathrm{hr}$ prior to laparoscopy examination. 
Data were statistically analyzed according to SAS (1996). Duncan Multiple Range Test was used to test the differences among means (Duncan, 1955).

\section{RESULTS AND DISCUSION}

Effect of rbST treatment on productive performance of ewes:

Change in live body weight:

Results in Table (1) show that LBW of ewes at late pre-partum and early post-partum (suckling period) was not affected by rbST treatment. However, treated ewes were significantly $(P<0.05)$ heavier by about $5 \%$ than controls only during late post-partum [May breeding season (from April to June)].

Table (1): Live body weight $(\mathrm{kg})$ of ewes in treatment and control groups during different physiological stages.

\begin{tabular}{|l|c|c|c|}
\hline \multicolumn{2}{|c|}{ Period (day) } & Experimental group & \multirow{2}{*}{ Significance } \\
\cline { 2 - 4 } & Control & Treatment & \\
\hline Late pregnancy (Jan. -Feb.): & $53.30 \pm 0.19$ & $53.25 \pm 0.44$ & $\mathrm{NS}$ \\
\hline 30 days pre-partum & $55.9 \pm 0.44$ & $55.9 \pm 0.38$ & $\mathrm{NS}$ \\
\hline 15 days pre-partum & $45.9 \pm 0.51$ & $48.4 \pm 0.93$ & $\mathrm{NS}$ \\
\hline At lambing & $48.9 \pm 0.96$ & $50.2 \pm 0.93$ & $\mathrm{NS}$ \\
\hline Suckling period (Feb. -March): & $49.5 \pm 0.98$ & $50.8 \pm 0.64$ & $\mathrm{NS}$ \\
\hline 30 days post-partum & $49.9 \pm 0.96$ & $52.2 \pm 0.52$ & ${ }^{*}$ \\
\hline 60 days post-partum & $50.4 \pm 0.98$ & $53.6 \pm 0.60$ & ${ }^{*}$ \\
\hline Mating period (April-June): & NS = Not significant \\
\hline 90 days post-partum &
\end{tabular}
* Significant differences at P<0.05 days post-partum

Davis et al. (1999) reported that the body weight of does did not affected by rbST treatment in multiparous Angora does injected with rbST (100 mg/kg BW/d). Moreover, Binelli et al., (1995) observed no differences in feed intake and body weight due to rbST treatment in primiparous cows received rbST $(29 \mathrm{mg} / \mathrm{d})$ for 63 d. They also, reported that energy balance was lower $(P<0.05)$ for rbST-treated than untreated cows. This study indicated that, in the overall process of nutrient partitioning, body weight was not impaired as a consequence of the greater demand for nutrients by the mammary gland in rbST-treated ewes.

Milk production (yield and composition):

Milk yield:

Data of milk yield presented in Table (2) show that average daily milk yield was significantly $(\mathrm{P}<0.05)$ higher in rbST treated ewes than that of the controls from the $2^{\text {nd }}$ week during the lactation period. The magnitude of increase ranged between 16 to $33 \%$. Subsequent lactation studies substantiated the positive response of milk yield to administration rbST. Quality of management will be the major factor affecting the magnitude of milk response to rbST. Factors that constitute the quality of the overall management program include the herd health program, milking practices, nutrition program and environmental conditions.

West (1994) and Putuam et al. (1999) reported that it is important to ensure that the commercial use of rbST not only increases cow milk volume, but also improves the efficiency with which the milk is produced. The magnitude of 
milk yield in response to rbST treatment were reported to increase by $7,19,21$ and $24 \%$ with $5,10,15$ and $20 \mathrm{mg} / \mathrm{d}$ (West et al., 1990); 14, 21 and $16 \%$ with 10.3, 20.6 and $41.2 \mathrm{mg} / \mathrm{d}$ (Burton et al., 1990); 7 and $9 \%$ with 10.3 and $25 \mathrm{mg} / 14$ d (Zhao et al., 1992); 9, 14 and 12\% with 11.4, 22.8 and $18 \%$ with $250 \mathrm{mg} / 14 \mathrm{~d}$ (Ocampo et al., 1995). According to (Chilliard et al., 1991), daily injection with 10 to $50 \mathrm{mg} / \mathrm{d}$ of rbST increased cows' milk production by 4.1 to $6.2 \mathrm{~kg} / \mathrm{d}$. Administration of 320 to $960 \mathrm{mg} / \mathrm{d}$ in a sustained-release vehicle formulation increased milk production by 1.5 to $3.4 \mathrm{~kg} / \mathrm{d}$. This increase was $4.7 \mathrm{~kg} / \mathrm{d}$ with 500 $\mathrm{mg} / 14 \mathrm{~d}$ of rbST in a sustained-release preparation. $\mathrm{GH}$ is the major galactopoietic's hormone in cows and is commonly used to increase milk yield in commercial dairy herds Peel et al. (1983). Treatment of dairy cows with bovine growth hormone increased milk yield generally by $10-40 \%$, by affecting both mammogenesis and lacto genesis Peel et al. (1981). Other studies indicated that, treatment dairy cows with exogenous growth hormone $(51.5 \mathrm{lU} / \mathrm{d})$ increased milk yield by $9.5-15 \%$ in early lactation and $31 \%$ in late lactation Hull and Harvey (2001).

Table (2): Average daily milk yield (kg) during the suckling period of ewes in treatment and control groups.

\begin{tabular}{|c|c|c|c|}
\hline $\begin{array}{c}\text { Lactation period } \\
\text { (week) }\end{array}$ & Control & Treatment & Significance \\
\cline { 2 - 4 } & $0.433 \pm 0.006$ & $0.475 \pm 0.011$ & $\mathrm{NS}$ \\
\hline 1 & $0.468 \pm 0.011$ & $0.542 \pm 0.012$ & ${ }^{*}$ \\
\hline 2 & $0.493 \pm 0.012$ & $0.593 \pm 0.012$ & ${ }^{*}$ \\
\hline 4 & $0.513 \pm 0.011$ & $0.621 \pm 0.011$ & ${ }^{*}$ \\
\hline 5 & $0.531 \pm 0.012$ & $0.660 \pm 0.012$ & ${ }^{*}$ \\
\hline 6 & $0.557 \pm 0.011$ & $0.716 \pm 0.012$ & ${ }^{*}$ \\
\hline 7 & $0.578 \pm 0.012$ & $0.767 \pm 0.011$ & ${ }^{*}$ \\
\hline 8 & $0.593 \pm 0.013$ & $0.740 \pm 0.012$ & \\
\hline Overall mean \pm SE & $0.521 \pm 0.010$ & $0.640 \pm 0.012$ & \\
\hline
\end{tabular}

* Significant differences at $\mathbf{P}<0.05 \quad \mathrm{NS}=$ Not significant

In case of sheep, Fernandez et al. (1995) used 74 lactating dairy ewes injected with rbST at $0,80,160$ or $240 \mathrm{mg}$ every 14 day from 3 to 8 weeks of lactation (T1) and 0,80 or $160 \mathrm{mg}$ every 14 day from 11 to 23 weeks of lactation (T2). They showed that rbST treatment increase milk yield $(P<0.01)$ at all treatments over the control. The largest increase in milk yield was at $160 \mathrm{mg}$ of rbST by which milk yields increased by 34.1 and $53.2 \%$ and $6 \%$ fat corrected milk by 36.9 and $51.8 \%$ for treatments 1 and 2 , respectively.

Few experiments have been carried out using bST with lactating ewes, but none has used a sustained-release formulation. Westbrook et al. (1993) utilized the immunization against somatotropin release-inhibiting factor; Sandles et al. (1988), and McDowell et al. (1988) used daily bST injections; and McDowell et al. (1987) used intra-arterial infusions of growth hormone.

It is established that administration of growth hormone enhances milk production in dairy ruminants, including goats (Bauman, 1999). Administration of a slow-release formulation of bST to dairy ruminants improves lactation persistency by slowing down the post peak rate to decline (Baldi, 1999; Chiofalo 
et al., 1999). Moreover, Sejrsen et al. (1999) reported that administration of growth hormone at mid-lactation seems to cause an increase in the quantity of mammary parenchyma.

Binelli et al. (1995) suggested that rbIGF and rbST increased the secretary capacity of the mammary gland and their actions on galactopoiesis were though increased synthesis of milk per mammary cell.

Effect of bST on plasminplasminogen system is one of the possible mechanisms that can delay regression of the mammary tissue during the transition from late lactation to dry period (Turner and Huynh, 1991).

\section{Milk composition:}

Changes of milk composition during suckling period of ewes are shown in Table (3). Milk fat, protein and total solids contents were significantly $(P<0.05)$ lower in rbST treated ewes during the lactation period (8 weeks) than that of the control. Meanwhile, lactose and ash contents in milk of ewes did not affected significantly by rbST treatment.

The lack of change in milk composition (fat, protein, lactose and total solids) in rbST-treated goats observed by Davis et al. (1999) is consistent with previous reports in goats (Nielsen, 1988) and cattle (Dahl et al., 1991).

Consumer advocates and others have expressed concern about the safety of milk from rbST treated cows. Barbano and MLynch (1989) reported that the characteristics of milk from rbST-treated cows are within the normal range, except of a slight increase and decrease in milk fat and protein, respectively. Several investigators worked on dairy cows showed that the overall milk composition was not affected by rbST treatment with $100-780 \mathrm{mg} / 14 \mathrm{~d}$ (Burchard et al., 1990), $350 \mathrm{mg} / 14 \mathrm{~d}$ (Burchard et al., 1990), $500 \mathrm{mg} / 14 \mathrm{~d}$ (Phipps et al., 1990), 56-700 mg/14 d (Downer et al., 1993), $29 \mathrm{mg} / \mathrm{d}$ (Binelli et al., 1995) or 10.3-41.2 mg/d (Chalupa et al., 1996). Moreover, Phipps et al. (1996) observed no effect of prolonged release formulation of rbST in milk composition of Holstein cows. Additionally, Santos et al. (1999) observed no change in milk composition in lactation cows received rbST at early lactation for 90 day. They also reported that biweekly injection of rbST affects milk yield and composition in Holstein dairy cows fed low-energy diets or high-energy diets in advanced lactation (292 DIM). Milk composition was not significantly influenced by rbST administration; minor changes have been observed; fat and protein yields were significantly increased by rbST treatment (Santos et al., 1999).

\section{Performance of offspring:}

Live body weight of male and female lambs produced from both experimental groups during the suckling period are illustrated in Figures 1 and 2 . Male lambs suckled rbST-treated ewes exhibited significantly $(P<0.05)$ higher body weight from the $4^{\text {th }}$ week during suckling up to weaning week (week 6) comparing with the control. Moreover, female lambs of the treated ewes were significantly $(P<0.05)$ heavier than that of the control group during the interval from the $4^{\text {th }}$ to the $7^{\text {th }}$ week during suckling period. According to lambs weight male and female lambs of rbST-treated ewes reached the weaning weight $(12 \mathrm{~kg})$ earlier (at 6 and 7 weeks, respectively) than lambs of the control group (8 weeks). 
Table (3): Changes of milk composition during suckling period (week) of ewes in treatment and control groups.

\begin{tabular}{|c|c|c|c|c|c|c|c|c|}
\hline \multirow{2}{*}{ Item } & \multicolumn{8}{|c|}{ Suckling period (week) } \\
\hline & $1 \mathrm{wk}$ & 2 wk & 3 wk & 4 wk & 5 wk & $6 \mathrm{wk}$ & 7 wk & 8 wk \\
\hline \multicolumn{9}{|c|}{ Fat (\%): } \\
\hline Treat. & $\begin{array}{c}5.58 \\
\pm 0.26\end{array}$ & $\begin{array}{c}4.26 \\
\pm 0.05\end{array}$ & $\begin{array}{c}4.21 \\
\pm 0.06\end{array}$ & $\begin{array}{c}4.40 \\
\pm 0.08\end{array}$ & $\begin{array}{c}4.14 \\
\pm 0.06\end{array}$ & $\begin{array}{c}4.14 \\
\pm 0.04\end{array}$ & $\begin{array}{c}4.21 \\
\pm 0.02\end{array}$ & $\begin{array}{c}4.22 \\
\pm 0.09\end{array}$ \\
\hline Control & $\begin{array}{c}6.31 \\
\pm 0.18\end{array}$ & $\begin{array}{c}5.24 \\
\pm 0.19\end{array}$ & $\begin{array}{c}5.19 \\
\pm 0.19\end{array}$ & $\begin{array}{c}5.34 \\
\pm 0.24\end{array}$ & $\begin{array}{c}5.02 \\
\pm 0.25\end{array}$ & $\begin{array}{c}4.88 \\
\pm 0.21\end{array}$ & $\begin{array}{c}4.84 \\
\pm 0.21\end{array}$ & $\begin{array}{c}5.12 \\
\pm 0.27\end{array}$ \\
\hline Significance & * & * & * & * & * & * & * & * \\
\hline \multicolumn{9}{|c|}{ Protein (\%): } \\
\hline Treat. & $\begin{array}{c}4.13 \\
\pm 0.04\end{array}$ & $\begin{array}{c}4.01 \\
\pm 0.06\end{array}$ & $\begin{array}{c}3.91 \\
\pm 0.05\end{array}$ & $\begin{array}{c}3.81 \\
\pm 0.10 \\
\end{array}$ & $\begin{array}{c}3.99 \\
\pm 0.10\end{array}$ & $\begin{array}{c}3.99 \\
\pm 0.08\end{array}$ & $\begin{array}{c}4.02 \\
\pm 0.15\end{array}$ & $\begin{array}{c}3.77 \\
\pm 0.13\end{array}$ \\
\hline Control & $\begin{array}{c}5.54 \\
\pm 0.13\end{array}$ & $\begin{array}{c}4.55 \\
\pm 0.14\end{array}$ & $\begin{array}{c}4.25 \\
\pm 0.12\end{array}$ & $\begin{array}{c}4.25 \\
\pm 0.15 \\
\end{array}$ & $\begin{array}{c}4.48 \\
\pm 0.08\end{array}$ & $\begin{array}{c}4.38 \\
\pm 0.06\end{array}$ & $\begin{array}{c}4.36 \\
\pm 0.07\end{array}$ & $\begin{array}{c}4.45 \\
\pm 0.14\end{array}$ \\
\hline Significance & * & * & * & NS & * & * & NS & * \\
\hline \multicolumn{9}{|c|}{ Lactose (\%): } \\
\hline Treat. & $\begin{array}{c}5.12 \\
\pm 0.01 \\
\end{array}$ & $\begin{array}{c}5.13 \\
\pm 0.04 \\
\end{array}$ & $\begin{array}{r}4.35 \\
\pm 0.07 \\
\end{array}$ & $\begin{array}{r}4.30 \\
\pm 0.04 \\
\end{array}$ & $\begin{array}{c}4.44 \\
\pm 0.01 \\
\end{array}$ & $\begin{array}{c}4.31 \\
\pm 0.04 \\
\end{array}$ & $\begin{array}{c}4.26 \\
\pm 0.04 \\
\end{array}$ & $\begin{array}{c}4.44 \\
\pm 0.11 \\
\end{array}$ \\
\hline Control & $\begin{array}{c}5.25 \\
\pm 0.07\end{array}$ & $\begin{array}{c}5.38 \\
\pm 0.08\end{array}$ & $\begin{array}{c}4.42 \\
\pm 0.18\end{array}$ & $\begin{array}{c}4.55 \\
\pm 0.10\end{array}$ & $\begin{array}{r}4.19 \\
\pm 0.06\end{array}$ & $\begin{array}{c}4.46 \\
\pm 0.08\end{array}$ & $\begin{array}{c}4.52 \\
\pm 0.09\end{array}$ & $\begin{array}{c}4.40 \\
\pm 0.08\end{array}$ \\
\hline Significance & NS & NS & NS & NS & NS & NS & NS & NS \\
\hline \multicolumn{9}{|c|}{ Ash (\%): } \\
\hline Treat. & $\begin{array}{c}0.87 \\
\pm 0.003 \\
\end{array}$ & $\begin{array}{r}0.85 \\
+0.001 \\
\end{array}$ & $\begin{array}{c}0.84 \\
\pm 0.009 \\
\end{array}$ & $\begin{array}{c}0.86 \\
\pm 0.001 \\
\end{array}$ & $\begin{array}{r}0.85 \\
\pm 0.001 \\
\end{array}$ & $\begin{array}{c}0.85 \\
\pm 0.001 \\
\end{array}$ & $\begin{array}{c}0.85 \\
\pm 0.001 \\
\end{array}$ & $\begin{array}{c}0.85 \\
\pm 0.008 \\
\end{array}$ \\
\hline Control & $\begin{array}{c}0.81 \\
\pm 0.001 \\
\end{array}$ & $\begin{array}{r}0.85 \\
\pm 0.004 \\
\end{array}$ & $\begin{array}{c}0.82 \\
\pm 0.007 \\
\end{array}$ & $\begin{array}{c}0.84 \\
\pm 0.009 \\
\end{array}$ & $\begin{array}{c}0.84 \\
\pm 0.009\end{array}$ & $\begin{array}{c}0.85 \\
\pm 0.005\end{array}$ & $\begin{array}{c}0.85 \\
\pm 0.008\end{array}$ & $\begin{array}{c}0.85 \\
\pm 0.006\end{array}$ \\
\hline Significance & NS & NS & NS & NS & NS & NS & NS & NS \\
\hline \multicolumn{9}{|c|}{ Total solids (\%): } \\
\hline Treat. & $\begin{array}{l}15.79 \\
\pm 0.15\end{array}$ & $\begin{array}{l}14.20 \\
\pm 0.09\end{array}$ & $\begin{array}{l}13.33 \\
\pm 0.15\end{array}$ & $\begin{array}{r}13.39 \\
\pm 0.12\end{array}$ & $\begin{array}{r}13.40 \\
\pm 0.10\end{array}$ & $\begin{array}{l}13.23 \\
\pm 0.14\end{array}$ & $\begin{array}{l}13.35 \\
\pm 0.19\end{array}$ & $\begin{array}{l}13.28 \\
\pm 0.18\end{array}$ \\
\hline Control & $\begin{array}{l}16.91 \\
\pm 0.20\end{array}$ & $\begin{array}{c}15.87 \\
\pm 1.51 \\
\end{array}$ & $\begin{array}{r}14.81 \\
\pm 0.08 \\
\end{array}$ & $\begin{array}{r}14.79 \\
\pm 0.21 \\
\end{array}$ & $\begin{array}{r}14.55 \\
\pm 0.27 \\
\end{array}$ & $\begin{array}{r}14.89 \\
\pm 0.23 \\
\end{array}$ & $\begin{array}{r}14.58 \\
\pm 0.14 \\
\end{array}$ & $\begin{array}{r}14.83 \\
\pm 0.43 \\
\end{array}$ \\
\hline Significance & * & * & * & * & * & * & * & * \\
\hline
\end{tabular}

Moreover, average daily weight gain for male and female lambs suckled rbST- treated ewes were higher (221 and $182 \mathrm{~g} /$ day, respectively) than the control (163 and $170 \mathrm{~g} /$ day, respectively). The increase in daily weight gain was more pronounced in male lambs of rbST- treated ewes, where it was $36 \%$ over the control male lambs. Similar results were reported by Sallam et al. (2005 a\& b) in Rahmani lambs and goats, Davis et al. (1999) in goat and Bareille et al. (1997) in cows. In the present study the increase in lamb's weight detected is due to the increase in suckled milk in the rbST- treated ewes than the control, so lambs suckled treated ewes received more milk than that of the control. 
Abdel-Khalek, A. E. et al.

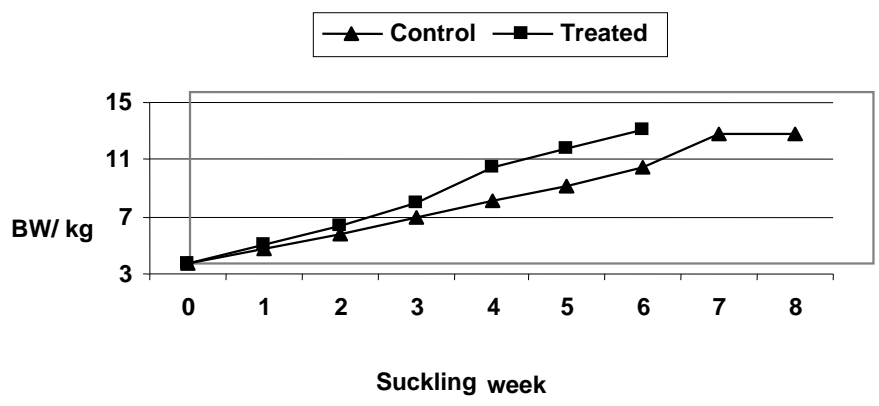

Fig. (1): Live body weight $(\mathrm{kg})$ of male lambs of control and treated ewes from birth till weaning.

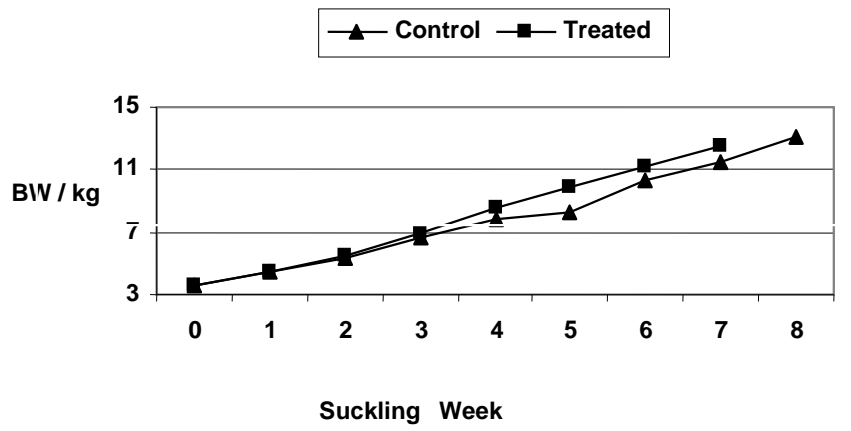

Fig. (2): Live body weight (kg) of female lambs of control and treated ewes at birth till weaning.

\section{Reproductive performance:}

Oestrous activity:

Results shown in Table (4) revealed that rbST treatment significantly $(\mathrm{P}<0.05)$ increased oestrus/ mating rate $(40 \mathrm{vs} .70 \%)$ and reduced post-partum period of lambing ewes by about one month ( $28 \mathrm{~d}$ ) as compared to untreated ewes. The results of the present study were confirmed by concentrations of progesterone detected during this period in both control and treated ewes (Figure 3 ). Serum progesterone levels increased in rbST- treated ewes reaching level $>1$ $\mathrm{ng} / \mathrm{ml}$ in the $3^{\text {rd }}$ week of March, while its level remain around $0.1-0.2 \mathrm{ng} / \mathrm{ml}$ in the control group. These results suggesting that rbST- stimulates estrus and in turn ovulation. 
Table (4): Oestrous activity of ewes in treatment and control groups.

\begin{tabular}{|l|c|c|c|}
\hline \multirow{2}{*}{ Item } & \multicolumn{3}{c|}{ Experimental group } \\
\cline { 2 - 4 } & Control & Treatment & Significance \\
\hline Total number of ewes & 20 & 20 & - \\
\hline Ewes exhibited oestrous activity & 8 & 14 & - \\
\hline Oestrus and mating rate (\%) & 40 & 70 & ${ }^{*}$ \\
\hline Days open & $93 \pm 4.96$ & $65 \pm 3.47$ & ${ }^{*}$ \\
\hline
\end{tabular}

* Significant differences at $\mathrm{P}<0.05$

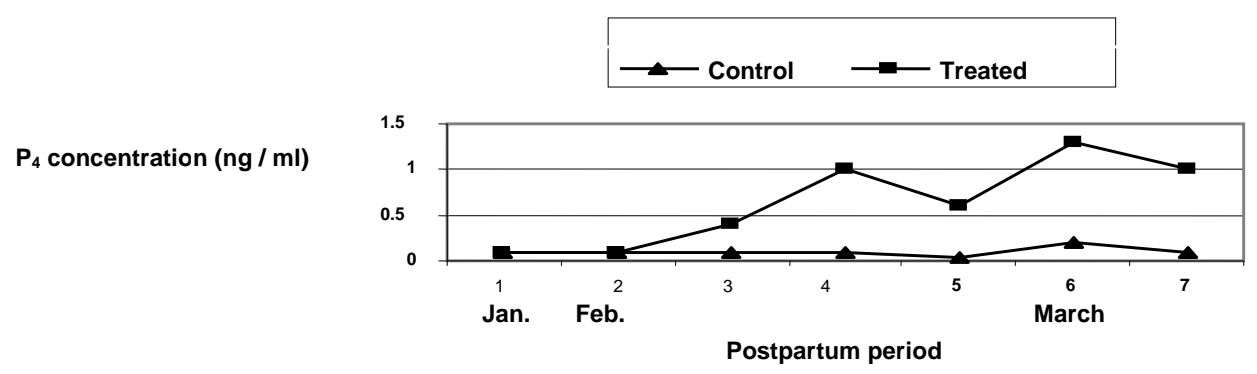

Fig. (3): Average progesterone levels ( $\mathrm{ng} / \mathrm{ml})$ in blood serum in the control and treated groups during post-partum period.

Reproductive efficiency of lactating dairy animals depends on some factors such as uterovarian health and activity, estrus detection, proper breeding, adequate nutrition and milk production (Esteban et al. 1994). Many studies have been evaluated the effects of rbST on dairy animal reproduction. These effects of rbST on reproduction were related to rbST dose-time of initiation of treatment, time of initiation of breeding and control of other factors such as nutritional status and milk production of cows (Esteban et al., 1994).

The increase in the rate of anoestrus confirmed by palpation in bSTtreated cows (Esteban et al., 1994) agreed with findings of less than optimal display of estrus in bST-treated cows as observed by Zhao et al. (1992) who also found an increase in the use of gonadotropin-releasing hormone $(\mathrm{GnRH})$. However, Esteban et al. (1994) concluded that before definite conclusions are made regarding reproductive performance, repercussions in milk production, energy balance, body condition score and blood metabolites that arise with the use of rbST should be considered.

The observed decreases in reproductive performance of dairy cattle treated with rbST may be attributed more to the increases in milk yield and shortterm negative energy balance than to direct effects of rbST (Weller et al., 1990). According to Phillips (1996), days open was more related to level of milk production than rbST. In addition, treatment with rbST increases milk energy output before there is a concomitant increase in feed intake and therefore, following initiation of rbST treatment, treated cows tend to be in more negative energy balance which is known to reduce reproductive performance. 
Abdel-Khalek, A. E. et al.

Ashmawy (2003) and Teleb et al. (2003) recoded progesterone levels between $<0.1$ to $<0.5 \mathrm{ng} / \mathrm{ml}$ during post-partum period (March to May) in Damascus goats. Teleb et al. (2003) reported an increase in plasma progesterone concentrations at mid of June indicating the occurrence of one or more ovulatory anoestrus. Progesterone levels during post-partum is negatively correlated with prolactin levels (i. e high prolactin levels are often associated with reductions in progesterone release and luteal function) as reported by Teleb et al. (2003). In present study lambs suckled rbST- treated ewes weaned two weeks earlier than the control, which could cause an increase in progesterone levels in the circulation and in turn stimulate the resumption of the cyclic activity.

\section{Ovarian activity:}

Laparoscopy examination of animals in treatment and control groups at 5-12 day after mating showed that total number of follicles and corpora lutae (CL's) was greater either on right or left ovarian surface of treated than control ewes. Total number of ovarian follicles and CL's was also grater in treated than in control ewes (Table 5).

Such trend indicated beneficial effects of rbST on ovarian activity and ovulation rate of treated ewes. However (Davis et al., 1990) reported that ovulation rate was not influenced by bST treatment in normally cyclic ewes. In heifers (Gong et al., 1991, 1993a) suggested that the number of small antral follicles was significantly increased in heifers treated with bST. Also, Spicer et al., (1992) reported an increase in the number of small antral follicles in obese gilts supplemented with porcine somatotropin. In contrast, Bryan et al. (1989) reported no change in the number or distribution of ovarian follicles in gilts supplemented with porcine ST, even though serum and follicular fluid concentrations of IGF-I was significantly increased. Gong et al. (1993b) reported an increase in ovulation rate and total number of embryos collected from heifers supplemented with bST and super ovulated with PMSG.

\section{Lambing performance:}

Lambing rate based on total number of ewes or number of mated ewes was significantly $(\mathrm{P}<0.05)$ lower in control than in treated ewes (30 and 75 vs. 60 and $85.7 \%$ ). Litter size of born lambs did not differ significantly in treated and control ewes (Table 6), although average number of CL was greater in treated than in control ewes (Table 5), which may indicate more ova wastage in treated ewes. 
Table (5): Laparoscopy examination of ovaries of ewes in treatment and control groups at 5-12 day after mating.

\begin{tabular}{|c|c|c|c|c|}
\hline \multirow{2}{*}{ Item } & \multicolumn{3}{c|}{ Experimental group } \\
\cline { 3 - 5 } & Follicles & Control & Treatment & Significance \\
\cline { 2 - 5 } \multirow{2}{*}{ Left ovary } & $\mathrm{CL}$ & 3 & 12 & ${ }^{*}$ \\
\hline \multirow{2}{*}{ Right ovary } & Follicles & 2 & 8 & ${ }^{*}$ \\
\cline { 2 - 5 } & $\mathrm{CL}$ & 7 & 13 & ${ }^{*}$ \\
\hline \multirow{2}{*}{ Total } & Follicles & 5 & 18 & ${ }^{*}$ \\
\cline { 2 - 5 } & $\mathrm{CL}$ & 10 & 21 & ${ }^{*}$ \\
\hline
\end{tabular}

${ }^{*}=$ Significant differences at $\mathrm{P}<0.05 \quad \mathrm{CL}=$ Corpus luteum

Table (6): Lambing performance of ewes in treatment and control groups.

\begin{tabular}{|l|c|c|c|}
\hline \multirow{2}{*}{\multicolumn{1}{|c|}{ Item }} & \multicolumn{3}{c|}{ Experimental group } \\
\cline { 2 - 4 } & Control & Treatment & Significance \\
\hline Total number of ewes & 20 & 20 & - \\
\hline Number of mated ewes & 8 & 14 & - \\
\hline Number of lambed ewes & 6 & 12 & - \\
\hline Lambing rate (\%) & 30 & 60 & ${ }^{*}$ \\
\hline Based on total number of ewes & 75 & 85.7 & ${ }^{*}$ \\
\hline Based on number of mated ewes & 9 & 20 & - \\
\hline Total number of born lambs & 1.50 & 1.54 & NS \\
\hline Litter size &
\end{tabular}

${ }^{*}=$ Significant differences at $\mathrm{P}<0.05 \quad \mathrm{NS}=$ not significant

Carrillo et al. (2007) reported that administration of single dose of bST 5 days before progestin withdrawal increases lambing rate and prolificacy in sheep, where this effects were associated with an increase in circulating concentrations of IGF-I. Moreover, ovarian follicles and corpora lutea are potential sites for GH action because of $\mathrm{GH}$ receptor which found within the granulosal cells as well as corpora lutea (Lucy et al., 1999). Other studies indicated that rbST supplementation did not affect ovulation rates in ewes and heifers (Davis et al., 1990 and Gong et al., 1993a, respectively). Nytes et al. (1990) working on dairy cows given $(0,10.3,20.6$ or $30.9 \mathrm{mg}) \mathrm{rbST} / \mathrm{d}$ from $14^{\text {th }}$ week after parturition for 30 weeks, observed no noticeable effects on reproductive performance due to rbST. Similar unaffected reproductive response was found in lactating cows given $\operatorname{rbST}(0,100,200,300,400$ or $780 \mathrm{mg})$ commenced at 100 days post-partum and continued until cows dried off (Burchard, 1990).

\section{Conclusion:}

Administration of $160 \mathrm{mg} \mathrm{rbST}$ at 14 days intervals during the pre- and post-partum period has proven its efficiency to increase milk yields and lambs growth in Rhamani crossbreed ewes without adverse effect on ewes or lambs health. Reproductive performance of ewes has been improved by rbST administration. 


\section{REFERENCES}

Akers, R. M. (2002). Lactation and the mammary gland. A Blackwell Publishing Company, lowa State press, 2121 State Avenue, Ames, lowa State, USA.

A.O.A.C. (1984). Official methods of analysis, 14 th ed. Association of Official Analytical Chemists. Washington DC.

Ashmawy, T. A. M. (2003). Physiological studies on goats. Ph. D. Thesis, Fac. Agric., Mansoura Univ.

B.S.I., (1952). Methods for the chemical analysis of cheese. British Standard Institute. (B.S.I.) No.770.

Baldi, A. (1999). Manipulation of milk production and quality by use of Somatotropin in dairy ruminants other than cow. Domest. Anim. Endocri., 17(2-3):131.

Barbano David M. and Joanna Mlynch (1989). Milk Form bst Treated Cows: Composition and Manufacturing Properties" Advanced Technologies Facing the Dairy Industry: bst .Cornell University.

Bareille, N.; P. Faverdin and M. Hay; (1997). Modification of feed intake response to B2-agonist by bovine somatotropin in lactating or dry cows. J. Dairy Sci., $80: 52$.

Barnett, A. J. and G. Abdel-Tawab (1957). A rapid method for determination of lactose in milk and cheese. J. Sci. Food Agric., 8 (7):437-441.

Bauman, D. E.; (1999). Bovine somatotropin and lactation: From basic science to commercial application.Domest. Anim. Endocri. 17:101-116.

Bauman, D.E (1987). Bovine somatotropin the cornell exper. lence . Page 46 in proc. Nath.Invitational work shop on bovine somatotropin, USA Ext. Ser Washington, DC.

Binelli, M.; W. K. Vander Kool; L. T. Chapin; M. J. Vandhaar, J. D. Turner; W. M. Moseley and H. A. Tucker (1995). Comparison of growth hormone releasing factor and somatotropin: Body growth and lactation of primiparous cows J. Dairy Sci., 78: 2129.

Bitman, J. D.; L.Wood; H. F. Tyrell; D. E. Bauman, C . J. Peel; A. C. G. Brown and P. J. Reynolds (1984). Blood and milk lipid responses induced by growth hormone administration to lactating cows. J. Dairy Sci., 67:28732888.

Bojanic, S. ; R. Lake ; J. Place ; L. Jones ; J. Laycoock ; G. Carter and J. AlaghBand-Zadeh (1991). Serum progesterone concentration is raised during early follicular phase in women with polycystic ovaries. Ann. Clin. Biochem., 28: 105-106.

Bryan, K. A., J. M. Hammond, S. Canning, J. Mondschein, D. E. Carbaugh, A. M. Clark, and D. R. Hagen (1989). Reproductive and growth responses of gilts to exogenous porcine pituitary growth hormone. J. Dairy. Sci., 67:196.

Burchard, J. F.; M. Gallo; Mckiddie and E. Block (1990).Effect of bovine somatotropin on milk yield in dairy cows. Brief communication of the $x \times 1$. International Dairy Congress, Montreal. October 8-12. Vol, 1. 
Burton, J.L.; B. W. McBride; B. W. Kennedy; J. H. Burton T. H. Elsasser and B. Woadward (1990). Rbst and the bovine immune system. Brief Communication of the XXIII International Dairy Congress, Montreal, October 8 - 12. Vol. (1): 80.

Carrillo, F, J. Hernández-Cerón, V. Orozco, J.A. Hernández and C.G. Gutiérrez (2007). A single dose of bovine somatotropin 5 days before the end of progestin-based estrous synchronization increases prolificacy in sheep. Anim. Reprod. Sci., Vol. 102 (1-2): 31-37.

Chalupa, W., B. Vecchiarelli, D. T. Galligan, J. Ferguson, L. S. Baird, R. W. Hemken, R. J. Harmon, C. G. Soderholm, D. E. Otterby, R. J. Annexstad, J. G. Linn, W. P. Hansen, F. R. Ehle, D. L. Palmquist, and R. G. Eggert (1996). Responses of dairy cows supplemented with somatotropin during weeks 5 through 43 of lactation. J. Dairy Sci. 79:800-812.

Chilliard, Y.; M.Cissie;R. Lefaivre and B. Remond (1991). Body composition of dairy cows according to lactating stage, somatotropin treatment, and concentrate supplementation. J. Dairy Sci. 74:3103-3116.

Chiofalo, V.; A. Baldi;G. Savoini; F. Polidori; V. Dell'Orto; and I. Politis (1999). Response of dairy ewes in late lactation to recombinant bovine somatotropin (rbST). Small Rum. Res. 34:119-125.

Dahl, G. E., L. T. Chapin, M. S. Allen, W. M. Moseley, and H. A. Tucker(1991). Comparison of somatotropin and growth hormone realizing factor on milk yield, serum hormones, and energy status. J. Dairy Sci. 74:3421.

Davis, J .J, T. Sahlu; R. Puchala; M. J. Herselman; J. M. Fernandez J. P. Mccann and S. W. Coleman (1999). The effect of bovine somatotropin treatment on production of lactating Angora dose with Kids .J. Anim. Sci.77: 17.

Davis, S. R., J. F. Smith, and P. D. Gluckman (1990). Effects of growth hormone injections on ovulation rate in ewes. Reprod. Fertil. Dev. 2:173.

Deghedy, A. M. (2006). Studies on ovarian follicular development in different crossbred ewes during breeding and out-breeding of season.Ph.D.Thesis, Fac. Agric. Kafrelshiekh, Tanta Univ.

Downer; J.V., D. L. Patterson, D. W. Rock, W.V. Chalupa, R. M. Cleale, J.L. Firkins, G.L. Lynch. J. H. Clark, B.O. Borodie, B.F. Jenny and R.D.E Gregorie (1993). Dose titration of sustained. Release recombinant bovine somatotropin in lactating dairy cows. J. Dairy Sci., 76: 1125.

Duncan, D. B. (1955). Multiple Range and Multiple F-test Biomatrics 11:1-42.

Eppard, P. J., D. E. Bauman, and S.N.McCutcheon (1985). Effect of dose of bovine growth hormone on lactation of dairy Cows.J. Dairy Sci., 68:11091115.

Esteban, E; P. H. Kass; L. D. Weaver; J. D. Rowe; C. A. Holmberg C. E. Franti and $\mathrm{H}$. Fred Troutt (1994). Reproductive performance in high producing cows treated with recombinant bovine somatotropin. J. Dairy Sci. 77:3371.

Fernandez, N., M. Rodriguez, C. Peris, M. Barceld, M.P. Molina. A. Torres and F. Andiaens(1995). Bovine somatotropin titration in lactating dairy ewes. Milk yield and milk composition. J. Dairy Sci., 78: 1073.

Gallo, L.; L. Bailoni,S. Schiavon, P. Carnier, M. Ramanzin, I. Andrighetto, and G. Bittante (1997). Effect of slow-release Somatotropin on the pattern of milk yield between and within injection intervals. J. Dairy Sci. 80:46-51. 
Gong, J.G.; T. A Bramley and R. Webb (1993a). The effect of recombinant bovine somatotropin on ovarian follicular growth and development in heifers. J. Reprod. Fertil.97:247.

Gong, J.G.; T. A. Bramley; I. Wilmut, and R. Webb (1993b). Effect of recombinant bovine somatotropin on the superovulatory response to pregnant mare serum gonadotropin in heifers. Biol. Reprod. 48:1141.

Gong, J.G.; T. A. Bramley and R. Webb (1991). The effect of recombinant bovine somatotropin on ovarian function in heifers: Follicular populations and peripheral hormones. Biol.Reprod. 45:941.

Hull, K. L.; and S. Harvey (2001). Growth hormone: roles in female reproduction. J. Endocri., 168:1-23.

Knight, C. H. (1992): Milk yield responses to sequential treatments with recombinant bovine somatotropin and frequent milking in lactating goats. J. Dairy Res. 59:115.

Ling, E. R. (1963). A Text Book Of Dairy Chemistry. 3rd ed., Vol.2. Chapman and Hall, London, UK.

Lucy, M. C.; C. R. Bilby; C. J. Kirby; W. Yuan and C. K. Boyd (1999). Roles of growth hormone in development and maintance of follicles and corpora lutea. J. Rep. Fertile. Suppl., 54: 49- 59.

McDowell, G. H., D. Lcenanuruksa, P. Nimsup. J. M. Gooden. J. G. Van Der Walt. and R. Snithard (1988). Short-term effects of exogenous growth hormone: effects on milk production and utilization of nutrients in muscle and mammary tissues of lactating ewes. Aust. J. Biol. Sci. 41:279.

McDowell, G. H., I. C. Hart, and A. C. Kirby (1987). Local intra-arterial infusion of growth hormone into the mammary glands of sheep and goats: effects on milk yield and composition, plasma hormones and metabolites. Aust. J. Biol. Sci. 40: 181.

Nielsen, M.O. (1988). Effect of recombinant derived bovine somatotropin on mammary gland synthetic capacity in lactating goats. J. Anim. Physiol. Anim. Nutr. 59, 263-272.

N. R. C. (1985). Nutrient Requirements of Sheep. Sixth Revised Edition, National research council, National academy press, Washington, D.C.

Nytes, A. J; D.K. Combs; G.E. Shook; R.D. Shaver and R.M. Cleale (1990). Response to recombinant bovine somatotropin (rbst) in dairy cows with different genetic merit for milk production J. Dairy Sci., 73: 784.

Ocampo, L.C; M. Morales; H. C. Basurto and A. A. Auro (1995). Effect of somatotropin on milk production of cross bred dairy cows in the tropics. Vet. Mexico. , 26: 137.

Peel, C. J., T. J. Fronk, D. E. Bauman, and R. C. Gorewit (1983). Effect of exogenous growth hormone in early and late lactation on lactational performance of dairy cows. J. Dairy Sci. 66:776-782.

Peel, C.J., Bauman, D.E., Gorewit, R.C., Sniffen, C.J. (1981). Effect of exogenous growth hormone on lactational performance in high yielding dairy cows. J Nutr 111:1662-1671.

Phillips, C. J. C. (1996). Progress in dairy science. Pages 59- 85. In: the effect of bovine somatotropin on dairy production, cow health and economics. Cab International Walling Ford, Oxan, UK. 
Phipps, R. H., V. Bines, and F. Adrians (1990). Use of prolonged release bovine somatotropin for milk production in British Friesian dairy cows. 3- Effect on manufacturing properties and qua of cheddar, Wensleydale and Cheshire Cheese. J. Agric.Sci.comb.115:113 -116.

Phipps, R.H.; F. Adriaens; D.L. Hard; G. Dekerchove; R.F.Weller and De G. Kerchove (1996). Use of bovine somatotropin for milk production: the effect of time of treatment initiation on milk production of Holstein / Friesian dairy cows placed on a high - forage - low concentrate feeding system - Grass and Forage. J. Dairy Sci., 51:111.

Putuam, D.E.; G. A. Varga, and H.M. Dann (1999).Metabolic and reproduction responses to dietary protein and exogenous somatotropin in late gestation dairy cows. J. Dairy Sci., 82 (5): 982-995.

Sallam, S. M.A., M.E.A. Nasser and M.I. Yousef (2005 a).Effect of recombinant bovine somatotropin administration on milk production, composition and some hemato-biochemical parameters of lactating goats. Egyptian J. Anim. Prod., 42 (1): 33- 46.

Sallam, S. M. A., M.E.A. Nasser and M.I. Yousef (2005b).Effect of recombinant bovine somatotropin administration on sheep milk production, composition and some hemato- biochemical parameters. Egyptian J. Anim. Prod., 56 (1): 165- 171.

Sandles, L. D., Y. X. Sun, A.G.C. D'Cruz, G. H. McDowell, and J. M. Gooden (1988). Responses of lactating ewes to exogenous growth hormone: short and long-term effects on productivity and tissue utilization of key metabolites. Aust. J. Biol. Sci. 41: 357.

Santos, J.E.P; J. I. Huber; L.G. Nussio; C. B. Nussio; M. Tarazon and R. O, LimaFilho (1999). Performance and nutrional digestibility by dairy cows treated with bovine somatotropine and fed diets with steam-flacked sorghum or steam - rolled corn during early lactation. J. Dairy Sci., 82: 404.

SAS (1996).User's Guide: Statistics, Version 6 Edition. 1996. SAS Inst., Inc., Cary, NC.

Sejrsen, K., S. Purup, M. Vestergaard, M. S. Weber, and C. H. Knight.(1999).Growth hormone and mammary development.Domest.

Spicer, L. J.; and M.T.Zavy (1992). Concentrations of insulin-like growth factor-I in serum of sheep with different ovulation rates: Changes during the estrous cycle. Theriogenology 37:395.

Stelwagen, K.; D. G. Grieve; J. S. Walton; J. L. Ball and B. W. McBride (1993): Effect of pre-partum bovine Somatotropin in Primisravid ewes on mammogenesis, milk production and J. hormone concentration. J. Dairy Sci., 76: 992.

Teleb, F. Doaa; M. K. Gabr; and Khadiga M. Gaafar (2003): Manipulation of lactation and suckling on the resumption of post-partum reproductive activity in Damascus goats. Small Ruminant Research, Volume 49, Issue 2, August, Pages 183-192.

Turner, J. D. and H. T. Huynh (1991). Role of tissue remodeling in mammary epithelial cell proliferation and morphogenesis. J. Dairy Sci., 74:2801.

Weller, R. F.; R. H. Phipps. N. Craven and C.J. Peel (1990) Use of a prolonged release bovine somatotropin for milk production in British Friesian dairy cows, J, Agric. Sci., 115:105. 
West, J. W; B. G. Mullinix and T.G.Sandifer (1990). Effects of bovine somatotropin on physiological responses of lactating Holstein and Jersey cows during hot, humid weather. J. Dairy Sci. 74:840.

West, J.W. (1994). Interactions of energy and bovine somatotropine with heat stress. J. Dairy Sci., 77: 2091-2102.

Westbrook, S. L., K. D. Chandler, and G. H. McDoweL (1993). Immunization of pregnant ewes against somatompin release inhibiting factor increases growth of twin lambs. Aust. J. Agric. Res., 44:229.

Zhao, X; J.H. Burton and B.W. Mcibride (1992).Lactation, health and reproduction of. J. Dairy Sci., 73: 1060.

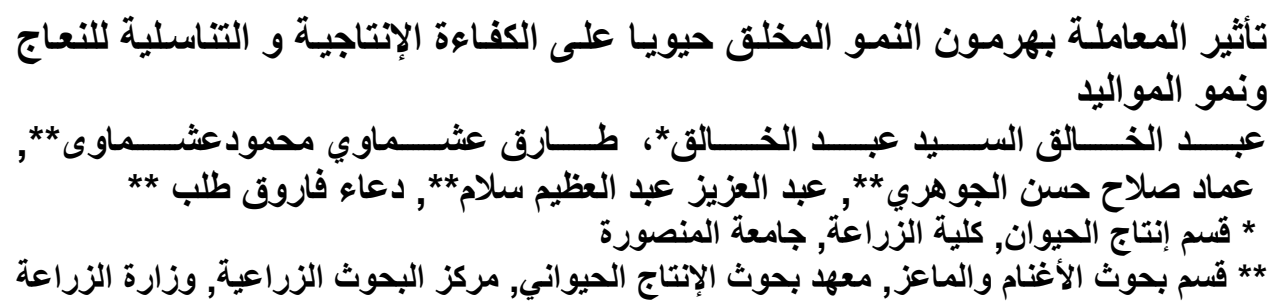

أجرى هذا البحث لدراسة تأثير هرمون النمو المخلق حيويا على إنتاج و مكونات اللبن و الكفاءة التناسلية

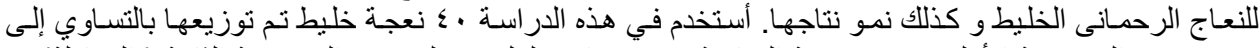

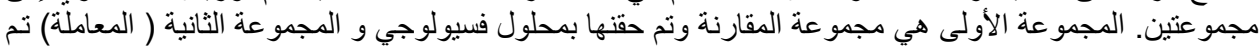

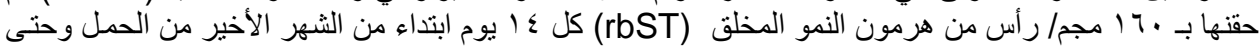

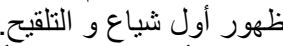

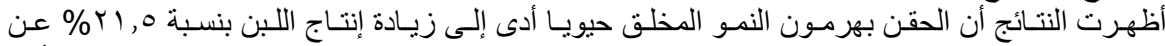

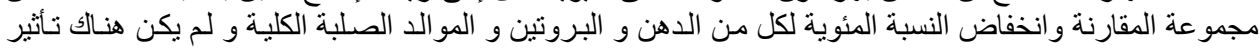

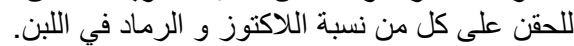

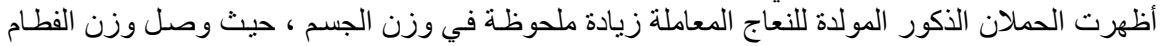

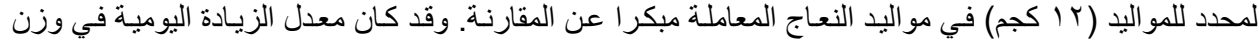

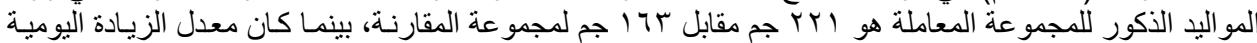

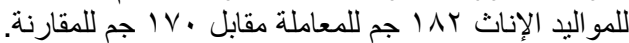

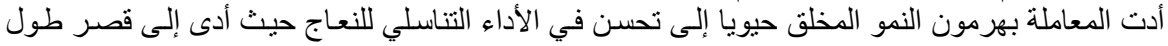

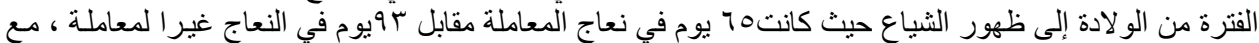

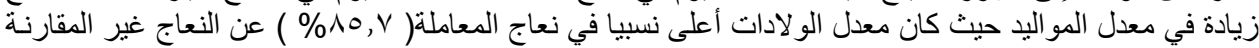

. (\% \%०)

وحيث أن المعاملة بهرمون النمو المخلق حيويا أعطت نتائج إيجابية في رفع الكفاءة الإنتاجية و التناسلية

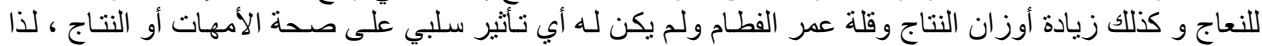

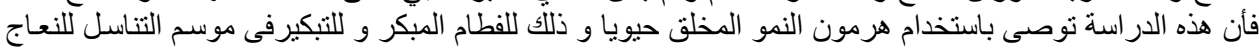

